Supplement of Geosci. Model Dev., 8, 2035-2065, 2015

http://www.geosci-model-dev.net/8/2035/2015/

doi:10.5194/gmd-8-2035-2015-supplement

(C) Author(s) 2015. CC Attribution 3.0 License.

(c) (i)

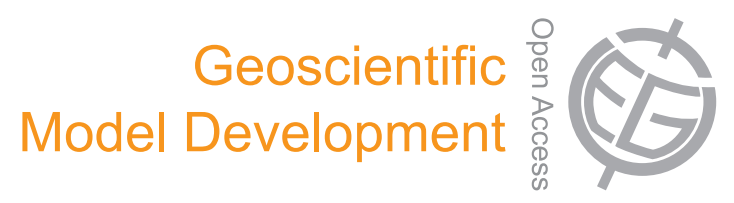

Supplement of

\title{
A vertically discretised canopy description for ORCHIDEE (SVN r2290) and the modifications to the energy, water and carbon fluxes
}

K. Naudts et al.

Correspondence to: K. Naudts (kim.naudts@1sce.ipsl.fr)

The copyright of individual parts of the supplement might differ from the CC-BY 3.0 licence. 


\section{Supplementary information}

This document contains the supplementary figures and tables of the manuscript 'A vertically discretised canopy description for ORCHIDEE (SVN r2290) and the modifications to the energy, water and carbon fluxes'. 


\subsection{Figures}
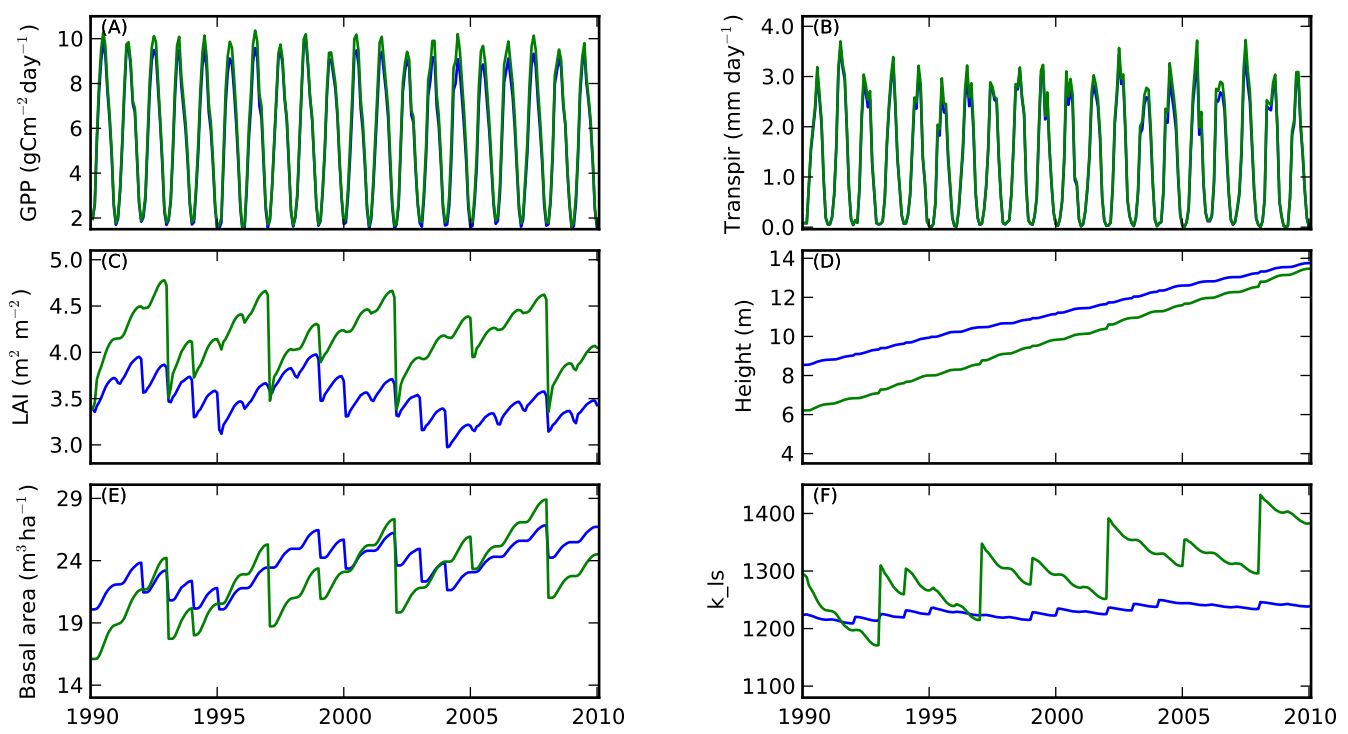

Figure S1. Impact of the optimization of $k_{c m a i n t}$ and $k_{l s m i n}$ for an unmanaged Scots pine forest at 51 $52{ }^{\circ} \mathrm{N}, 13-14^{\circ} \mathrm{E}$ for GPP (A), transpiration (B), LAI (C), tree height (D), basal area (E) and the ratio of leaf area to sapwood area $(\mathrm{F})$. The simulation with prior parameter values is shown in green $\left(k_{\text {cmaint }}=0.01\right.$ and $\left.k_{l s m i n, \max }=850-2000\right)$ and the simulation with optimized values is presented in blue $\left(k_{\text {cmaint }}=0.033\right.$ and $\left.k_{l s \min , \max }=1100-1395\right)$. 

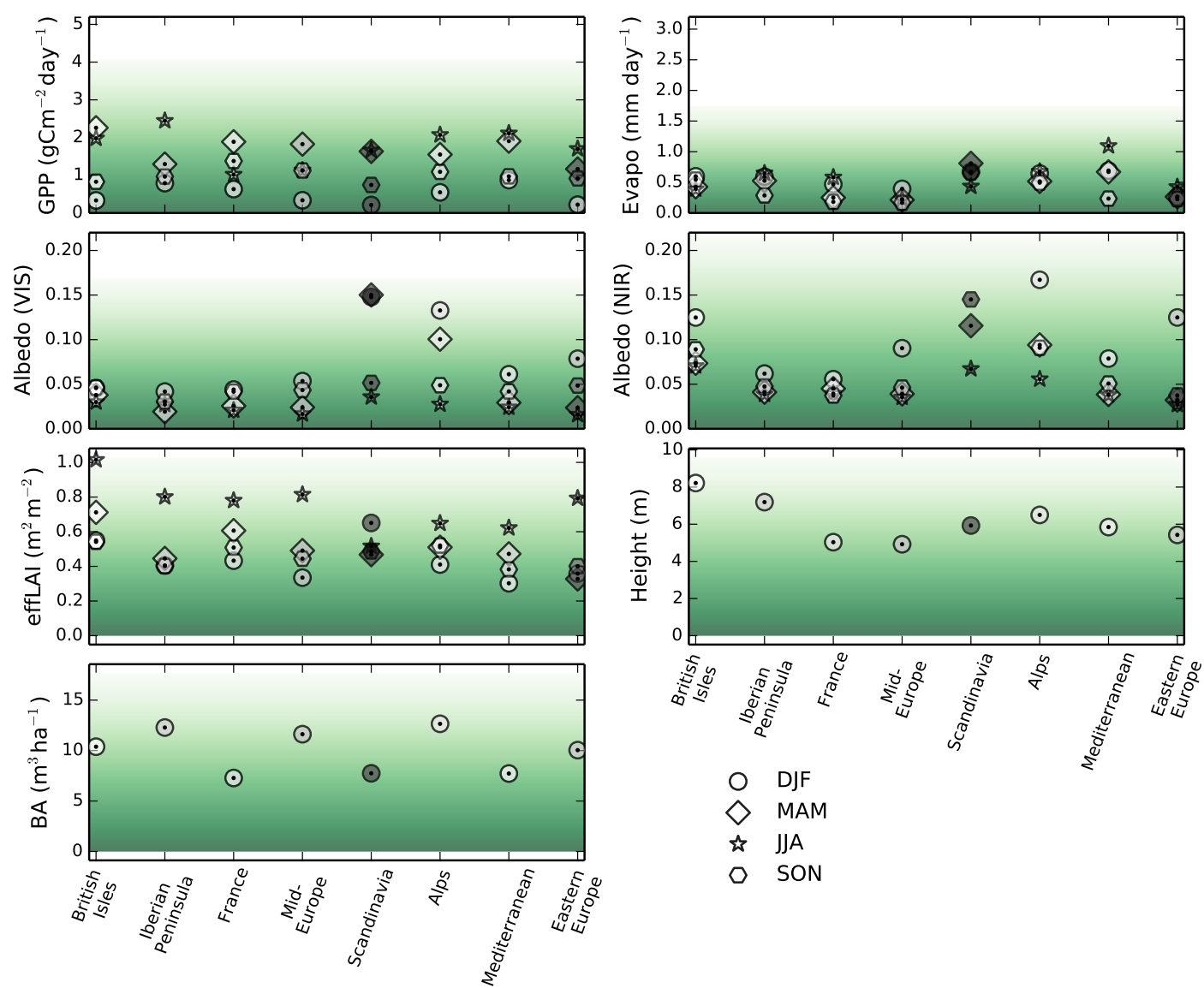

O DJF

$\diamond$ MAM

* JJA

- SON

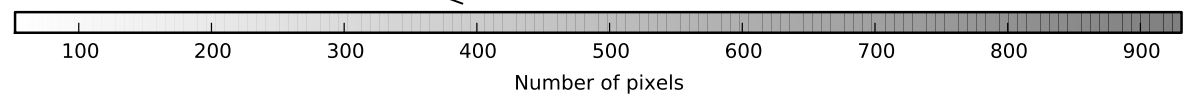

Figure S2. Root mean square error of an ORCHIDEE-CAN simulation with metaclass parameters. Results are shown for gross primary production, evapotranspiration, visible and near-infra-red albedo, effective leaf area index, basal area and height for different regions and periods (DJF: December-February, MAM: March-May, JJA: June-August, SON: September-November). The gray-scale of the symbols indicates the number of pixels included in the calculation. The transition from green to white indicates an RMSE of $100 \%$.

\subsection{Tables}









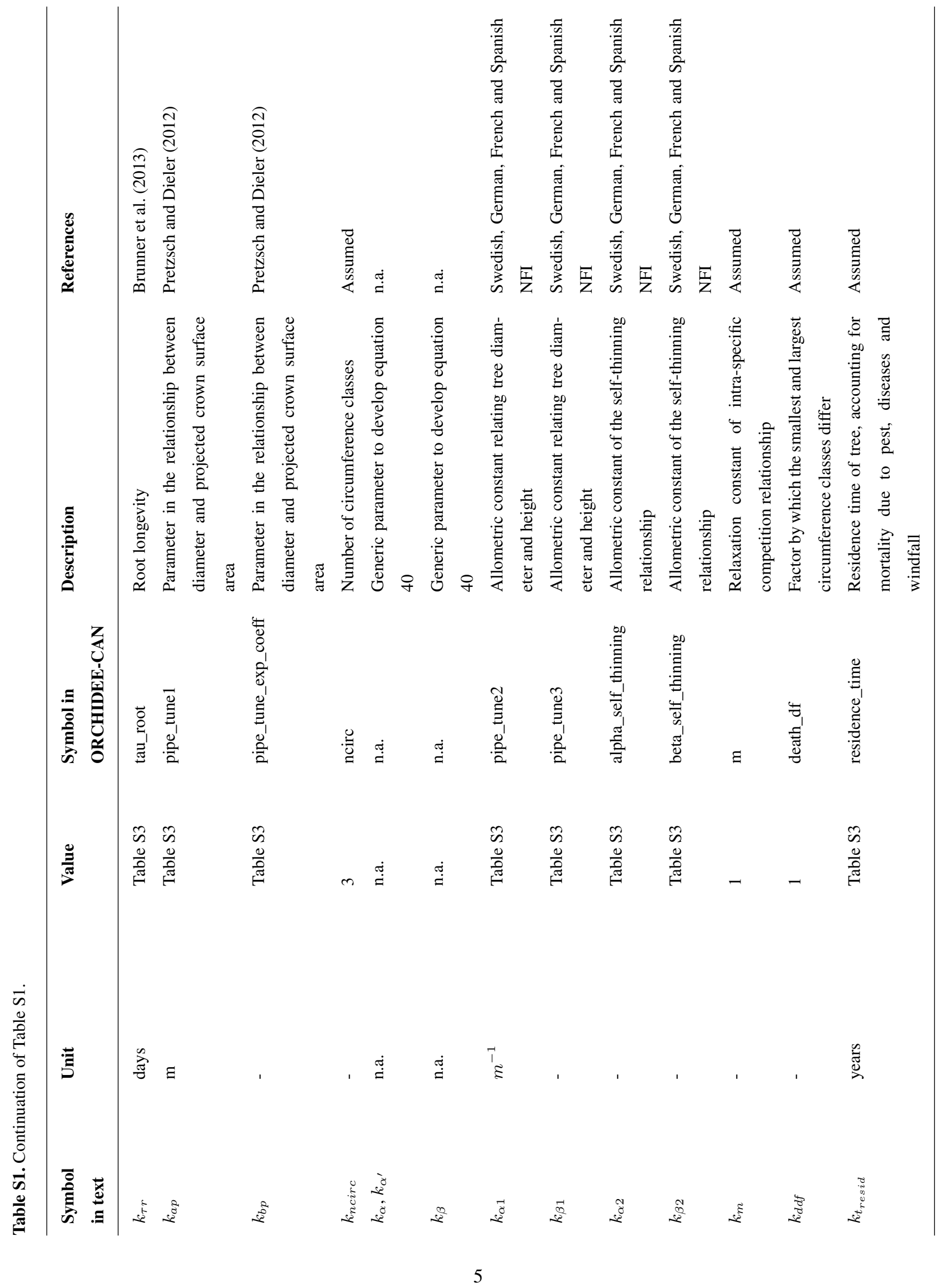




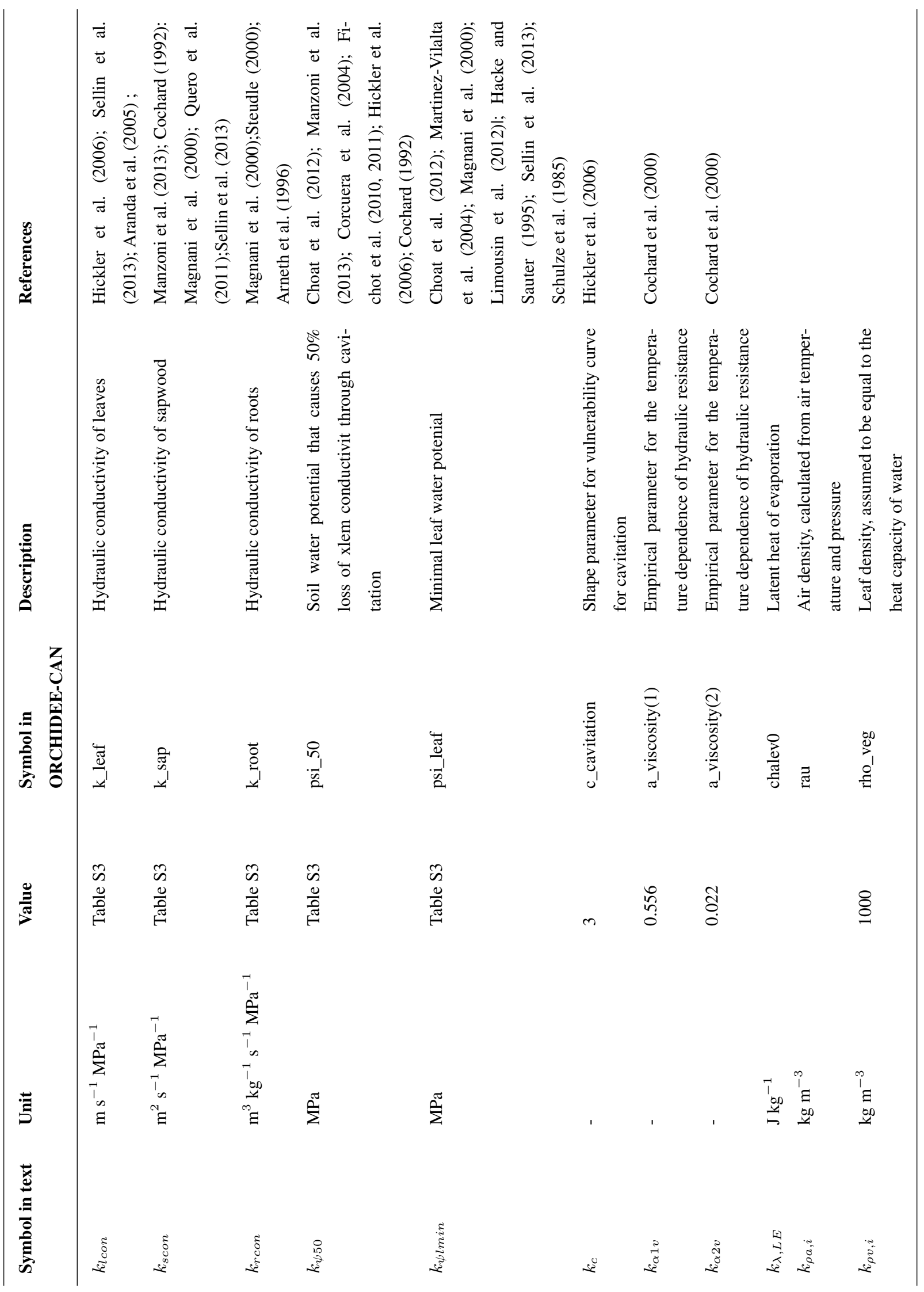




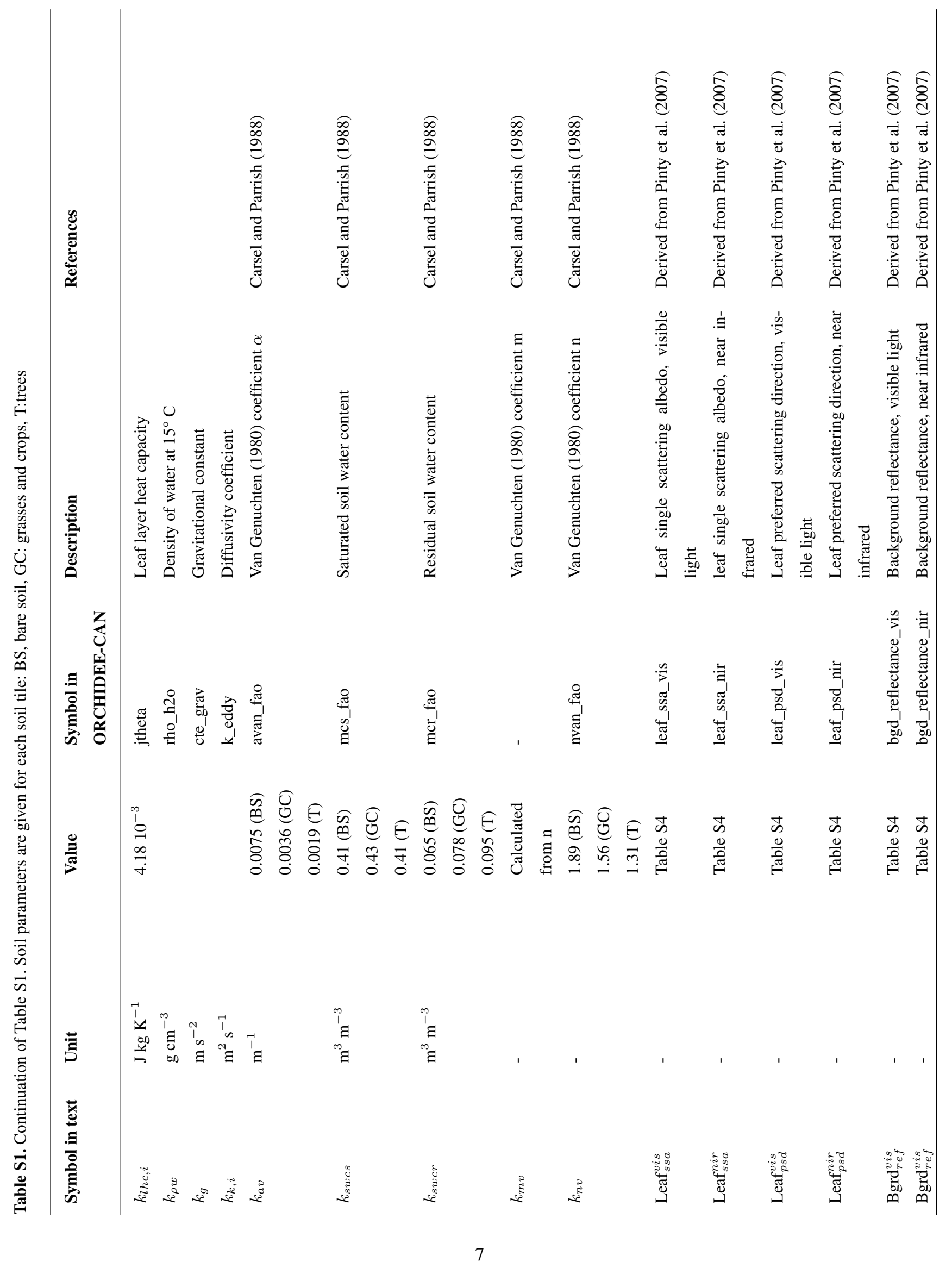




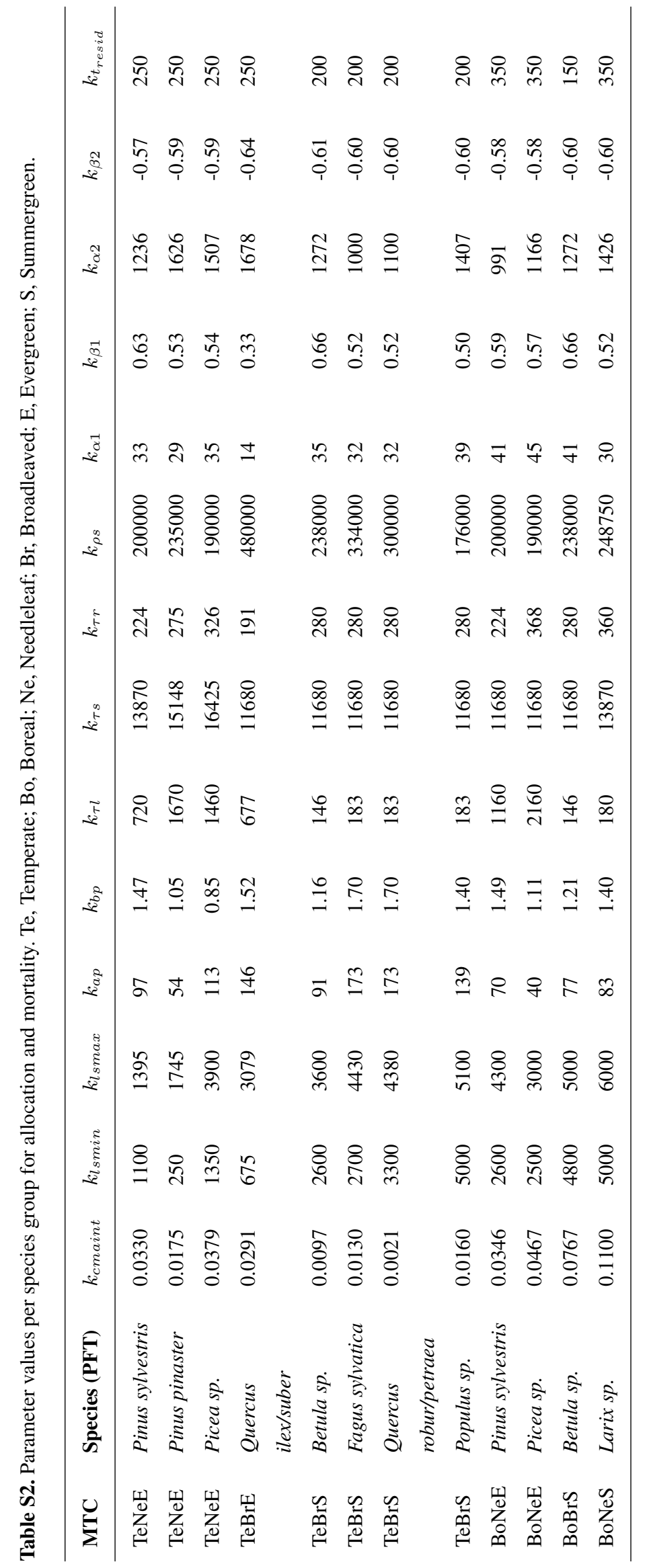




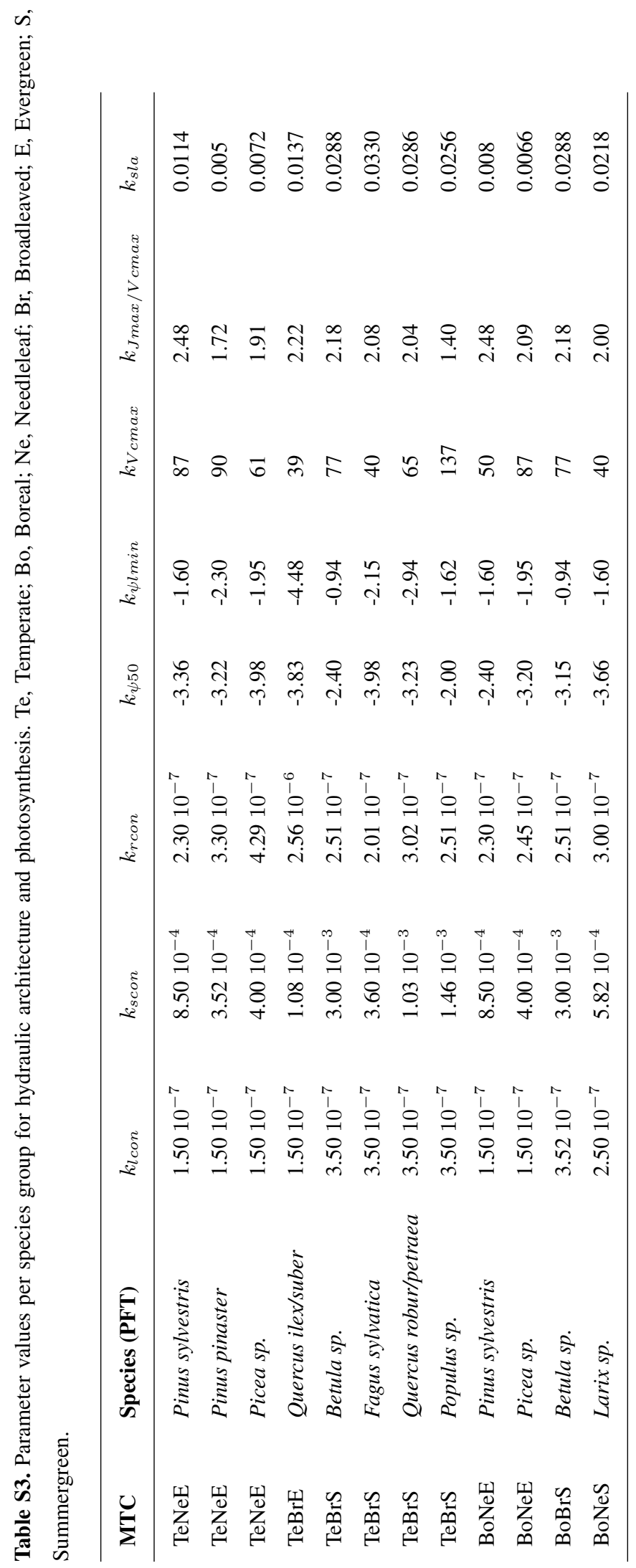




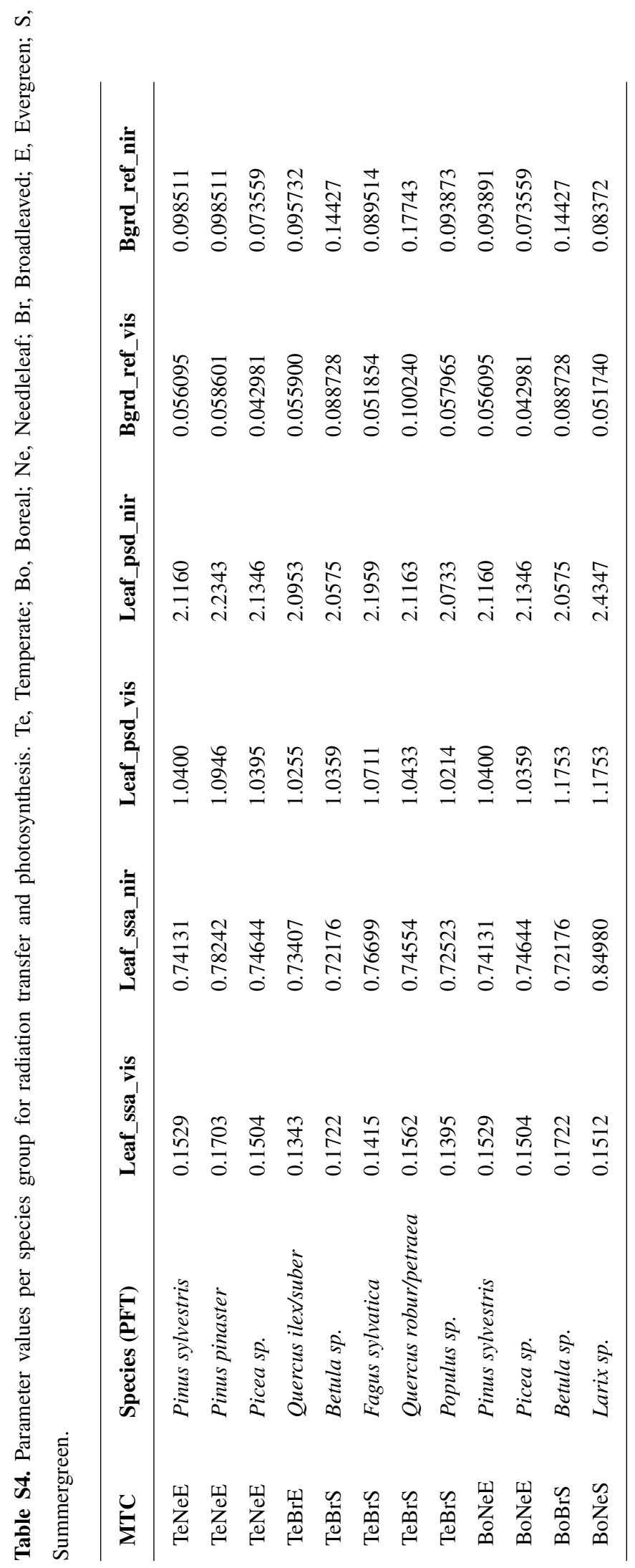




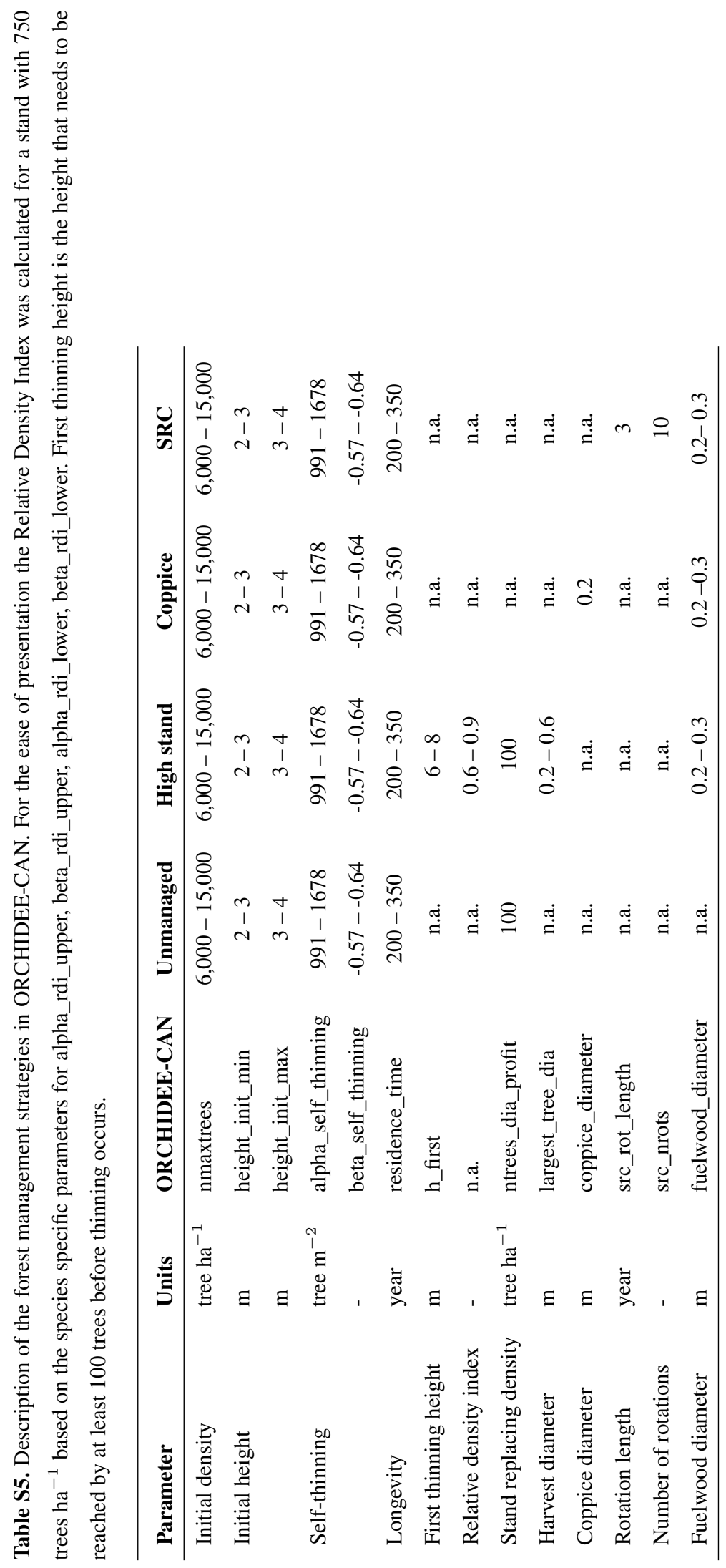




\section{References}

Aranda, I., Gil, L., and Pardos, J.: Seasonal changes in apparent hydraulic conductance and their implications for water use of European beech (Fagus sylvatica L.) and sessile oak [Quercus petraea (Matt.) Liebl] in

․ South Europe, Plant Ecology, 179, 155-167, doi:10.1007/s11258-004-7007-1 http://link.springer.com/10. 1007/s11258-004-7007-1, 2005.

Arneth, A., Kelliher, F. M., Bauer, G., Hollinger, D. Y., Byers, J. N., Hunt, J. E., Seveny, T. M. M. C., Ziegler, W., Vygodskaya, N. N., Milukova, I., Sogachov, A., Varlagin, A., and Schulze, E.-D.: Environmental regulation of xylem sap flow and total conductance of Larix gmelinii trees in eastern Siberia, Tree physiology, 16, 247-255, 1996.

Bartelink, H. H.: Allometric relationships for biomass and leaf area of beech (Fagus sylvatica L), Annals of Forest Science, 54, 39-50, 1997.

Berthier, S., Kokutse, A., Stokes, A., and Fourcaud, T.: Irregular Heartwood Formation in Maritime Pine (Pinus pinaster Ait): Consequences for Biomechanical and Hydraulic Tree Functioning, Annals of Botany, 87, 1925, doi 10.1006/anbo.2000.1290, http://aob.oxfordjournals.org/cgi/doi/10.1006/anbo.2000.1290 2001.

Björklund, L.: Identifying Heartwood-rich Stands or Stems of Pinus sylvestris by Using Inventory Data, Silva Fennica, 33, 119-129, 1999.

Bréda, N. and Granier, A.: Intra- and interannual variations of transpiration, leaf area index and radial growth of a sessile oak stand ( Quercus petraea ), Annals of Forest Science, 53, 521-536, 1996.

Brunner, I., Bakker, M. R., Björk, R. G., Hirano, Y., Lukac, M., Aranda, X., Bø rja, I., Eldhuset, T. D., Helmisaari, H. S., Jourdan, C., Konôpka, B., López, B. C., Miguel Pérez, C., Persson, H., and Ostonen, I.: Fine-root turnover rates of European forests revisited: an analysis of data from sequential coring and

] ingrowth cores, Plant and Soil, 362, 357-372, doi 10.1007/s11104-012-1313-5. http://link.springer.com/10. 1007/s11104-012-1313-5, 2013.

Carsel, R. F. and Parrish, R. S.: Developing joint probability distributions of soil water retention characteru istics, Water Resources Research, 24, 755-769, doi 10.1029/WR024i005p00755, http://doi.wiley.com/10. 1029/WR024i005p00755, 1988.

Choat, B., Jansen, S., Brodribb, T. J., Cochard, H., Delzon, S., Bhaskar, R., Bucci, S. J., Feild, T. S., Gleason, S. M., Hacke, U. G., Jacobsen, A. L., Lens, F., Maherali, H., Martínez-Vilalta, J., Mayr, S., Mencuccini, M., Mitchell, P. J., Nardini, A., Pittermann, J., Pratt, R. B., Sperry, J. S., Westoby, M., Wright, I. J., and Zanne, A. E.: Global convergence in the vulnerability of forests to drought., Nature, 491, 752-5, doi:10.1038/nature11688, http://www.ncbi.nlm.nih.gov/pubmed/23172141, 2012.

Cochard, H.: Vulnerability of several conifers to air embolism, Tree Physiology, 11, 73-83, doi $10.1093 /$ treephys/11.1.73, http://treephys.oxfordjournals.org/cgi/doi/10.1093/treephys/11.1.73 1992.

Cochard, H., Martin, R., Gross, P., and Bogeat-Triboulot, M.: Temperature effects on hydraulic conductance and water relations of Quercus robur L ., Journal of Experimental Botany, 51, 1255-1259, 2000.

Corcuera, L., Camarero, J. J., and Gil-Pelegrin, E.: Effects of a severe drought on Quercus ilex radial growth and xylem anatomy, Trees - Structure and Function, 18, 83-92, doi 10.1007/s00468-003-0284-9, http://link. springer.com/10.1007/s00468-003-0284-9. 2004.

David, T., Ferreira, M., Cohen, S., Pereira, J., and David, J.: Constraints on transpiration from an evergreen oak tree in southern Portugal, Agricultural and Forest Meteorology, 122, 193- 
205, doi 10.1016/j.agrformet.2003.09.014, http://linkinghub.elsevier.com/retrieve/pii/S0168192303002351. 2004.

50 Fichot, R., Barigah, T. S., Chamaillard, S., LE Thiec, D., Laurans, F., Cochard, H., and Brignolas, F.: Common trade-offs between xylem resistance to cavitation and other physiological traits do not hold among unrelated

] Populus deltoides x Populus nigra hybrids, Plant, cell \& environment, 33, 1553-68, doi:10.1111/j.13653040.2010.02164.x. http://www.ncbi.nlm.nih.gov/pubmed/20444213 2010.

Fichot, R., Chamaillard, S., Depardieu, C., Le Thiec, D., Cochard, H., Barigah, T. S., and Brignolas, F.: Hydraulic efficiency and coordination with xylem resistance to cavitation, leaf function, and growth performance among eight unrelated Populus deltoides x Populus nigra hybrids, Journal of Experimental Botany, 62, 2093-106, doi:10.1093/jxb/erq415, http://www.ncbi.nlm.nih.gov/pubmed/21193576 2011.

Gaspar, M. J. a., Louzada, J. L., Aguiar, A., and Almeida, M. H.: Genetic correlations between wood quality traits of Pinus pinaster Ait, Annals of Forest Science, 65, 703-703, doi 10.1051/forest:2008054, http://link. springer.com/10.1051/forest:2008054, 2008.

Gebauer, T., Horna, V., and Leuschner, C.: Variability in radial sap flux density patterns and sapwood area among seven co-occurring temperate broad-leaved tree species, Tree Physiology, 28, 18211830, doi 10.1093/treephys/28.12.1821, http://treephys.oxfordjournals.org/cgi/doi/10.1093/treephys/28.12. 1821, 2008.

65 Gould, P. J. and Harrington, C. A.: Extending sapwood - Leaf area relationships from stems to roots in Coast ㅁ Douglas-fir, Annals of Forest Science, 65, 802-802, doi 10.1051/forest:2008067 http://link.springer.com/ 10.1051/forest:2008067. 2008.

Hacke, U. and Sauter, J. J.: Vulnerability of xylem to embolism in relation to leaf water potential and stomatal conductance in Fagus sylvatica f . purpurea and Populus balsamifera, Journal of Experimental Botany, 46, 1177-1183, 1995.

Hickler, T., Prentice, I. C., Smith, B., Sykes, M. T., and Zaehle, S.: Implementing plant hydraulic architecture within the LPJ Dynamic Global Vegetation Model, Global Ecology and Biogeography,

15, 060811081017 001-???, doi 10.1111/j.1466-822X.2006.00254.x. http://onlinelibrary.wiley.com/doi/10. 1111/j.1466-8238.2006.00254.x/fullhttp://doi.wiley.com/10.1111/j.1466-822X.2006.00254.x. 2006.

75 Jenkins, J. C., Chojnacky, D. C., Heath, L. S., and Birdsey, R. A.: National-Scale Biomass Estimators for United States Tree Species, Forest Science, 49, 12-35, 2003.

Knapic, S., Louzada, J. L., Leal, S., and Pereira, H.: Within-tree and between-tree variation of wood density components in cork oak trees in two sites in Portugal, Forestry, 81, 465-473, doi $10.1093 /$ forestry/cpn012. http://forestry.oxfordjournals.org/cgi/doi/10.1093/forestry/cpn012 2008.

80 Limousin, J.-M., Rambal, S., Ourcival, J.-M., Rodríguez-Calcerrada, J., Pérez-Ramos, I. M., RodríguezCortina, R., Misson, L., and Joffre, R.: Morphological and phenological shoot plasticity in a Mediterranean 口 evergreen oak facing long-term increased drought, Oecologia, 169, 565-577, doi $10.1007 / \mathrm{s} 00442-011-2221-$ 8. http://www.ncbi.nlm.nih.gov/pubmed/22159896. 2012.

Longuetaud, F., Mothe, F., Leban, J.-M., and Mäkelä, A.: Picea abies sapwood width: Variations within and 85 between trees, Scandinavian Journal of Forest Research, 21, 41-53, doi 10.1080/02827580500518632 http: //www.tandfonline.com/doi/abs/10.1080/02827580500518632, 2006. 
Magnani, F., Mencuccini, M., and Grace, J.: Age-related decline in stand productivity : the role of structural acclimation under hydraulic constraints, Plant, cell \& environment, 23, 251-263, 2000.

Manzoni, S., Vico, G., Katul, G., Palmroth, S., Jackson, R. B., and Porporato, A.: Hydraulic limits on maximum plant transpiration and the emergence of the safety-efficiency trade-off., New Phytologist, 198, 169-78, doi:10.1111/nph.12126, http://www.ncbi.nlm.nih.gov/pubmed/23356378, 2013.

Margolis, H., Oren, R., Whitehead, D., and Kaufmann, M.: Leaf area dynamics of conifer forests, in: Ecophysiology of Coniferous Forests, edited by Smith, W. and Hinckley, T., pp. 181-223, Academic Press, 1995.

Martin, J. G., Kloeppel, B. D., Schaefer, T. L., Kimbler, D. L., and Mcnuity, S. G.: Aboveground biomass and nitrogen allocation of ten deciduous southern Appalachian tree species, Canadian Journal of Forest Research, 28, 1648-1659, 1998.

Martinez-Vilalta, J., Sala, A., and Pinol, J.: The hydraulic architecture of Pinaceae - a review, Plant Ecology, 171, 3-13, 2004.

McDowell, N., Barnard, H., Bond, B., Hinckley, T., Hubbard, R., Ishii, H., Köstner, B., Magnani, F., Marshall, J., Meinzer, F., Phillips, N., Ryan, M., and Whitehead, D.: The relationship between tree height and leaf a area:sapwood area ratio, Oecologia, 132, 12-20, doi 10.1007/s00442-002-0904-x. http://link.springer.com/ 10.1007/s00442-002-0904-x, 2002.

Meadows, J. S. and Hodges, J. D.: Sapwood area as an estimator of leaf area and foliar weight in cherrybark oak and green ash, Forest Science, 48, 69-76, 2002.

Mencuccini, M. and Bonosi, L.: Leaf/sapwood area ratios in Scots pine show acclimation across Europe, Cana] dian Journal of Forest Research, 31, 442-456, doi 10.1139/cjfr-31-3-442, http://www.nrc.ca/cgi-bin/cisti/ journals/rp/rp2_abst_e?cjfr_x00-173_31_ns_nf_cjfr31-01 2001.

Novick, K., Oren, R., Stoy, P., Juang, J.-Y., Siqueira, M., and Katul, G.: The relationship between reference canopy conductance and simplified hydraulic architecture, Advances in Water Resources, 32, 809_ 819, doi:10.1016/j.advwatres.2009.02.004 http://linkinghub.elsevier.com/retrieve/pii/S0309170809000232. 2009.

Pinty, B., Lavergne, T., Voß beck, M., Kaminski, T., Aussedat, O., Giering, R., Gobron, N., Taberner, M., Verstraete, M. M., and Widlowski, J.-L.: Retrieving surface parameters for climate models from Moderate Resolution Imaging Spectroradiometer (MODIS)-Multiangle Imaging Spectroradiometer (MISR) albedo

n products, Journal of Geophysical Research, 112, D10 116, doi 10.1029/2006JD008105, http://doi.wiley.com/ 10.1029/2006JD008105, 2007.

Pothier, D. and Margolis, H.: Analysis of growth and light interception of balsam fir and white birch saplings following precommercial thinning, Annals of Forest Science, 48, 123-132, 1991.

Pretzsch, H. and Dieler, J.: Evidence of variant intra- and interspecific scaling of tree crown structure

7. and relevance for allometric theory, Oecologia, 169, 637-49, doi 10.1007/s00442-011-2240-5 http://www. pubmedcentral.nih.gov/articlerender.fcgi?artid=3375085\\&tool=pmcentrezl\&rendertype=abstract 2012.

Quero, J. L., Sterck, F. J., Martínez-Vilalta, J., and Villar, R.: Water-use strategies of six co-existing Mediterranean woody species during a summer drought, Oecologia, 166, 45-57, doi 10.1007/s00442-011-1922-3. http://www.ncbi.nlm.nih.gov/pubmed/21290148, 2011.

Repola, J.: Models for Vertical Wood Density of Scots Pine, Norway Spruce and Birch Stems, and Their Application to Determine Average Wood Density, Silva Fennica, 40, 673-685, 2006. 
Ryan, M.: The effects of climate change on plant respiration, Ecological Applications, 1, 157-167, 1991.

Samuelson, L. J., Stokes, T. A., and Coleman, M. D.: Influence of irrigation and fertilization on transpiration and hydraulic properties of Populus deltoides, Tree physiology, 27, 765-774, 2007.

Schäfer, K. V. R., Oren, R., and Tenhunen, J. D.: The effect of tree height on crown level stomatal conductance, Plant, Cell and Environment, 23, 365-375, 2000.

Schulze, E.-D., Cermak, J., Matyssek, R., Penka, M., Zimmerman, R., Vasicek, F., Gries, W., and Kucera, J.: Canopy transpiration and water fluxes in the xylem of the trunk of Larix and Piceu trees - a comparison of xylem flow, porometer and cuvette measurements, Oecologia, 66, 475-483, 1985.

Schulze, E.-D., Schulze, W., Kelliher, F., Vygodskaya, N., Ziegler, W., Kobak, K., Arneth, A., Kusnetsova, W., Sogatchev, A., Issajev, A., Bauer, G., and Hollinger, D.: Abovegound biomass and nitrogen nutrition in a chronosequence of pistine Dahurian Larix stands in eastern Siberia, Canadian Journal of Forest Research, 25, 943-960, 1995.

Sellin, A., Tullus, A., Niglas, A., Õunapuu, E., Karusion, A., and Lõhmus, K.: Humidity-driven changes in growth rate, photosynthetic capacity, hydraulic properties and other functional traits in silver birch (Betula

] pendula), Ecological Research, 28, 523-535, doi/10.1007/s11284-013-1041-1, http://link.springer.com/10. 1007/s11284-013-1041-1, 2013.

Steudle, E.: Water uptake by plant roots: an integration of views, Plant and Soil, 226, 45-56, 2000.

Vincke, C., Granier, A., Bréda, N., and Devillez, F.: Evapotranspiration of a declining Quercus robur (L.) stand from 1999 to 2001. II. Daily actual evapotranspiration and soil water reserve, Annals of Forest Science, 62, 615-623, doi 10.1051/forest:2005060 http://www.edpsciences.org/10.1051/forest:2005060 2005.

Wullschleger, S. D., Meinzer, F. C., and Vertessy, R. A.: A review of whole-plant water use studies in trees, Tree Physiology, 18, 499-512, 1998. 